УДК 621.43

(C) 2014

Дудніков А. А., кандидат технічних наук,

Біловод О. І., кандидат технічних наук

Полтавська державіна аграрна академія

Пасюта А. Г., директор

Державне підприємство дослідного господарства «9 Січня»

Хорольського району Полтавської області

\title{
ПІДВИЩЕННЯ НАДІЙНОСТІ РОБОЧИХ ОРГАНІВ ГРУНТООБРОБНИХ МАШИН
}

\section{Рецензент - доктор технічних наук, професор О. В. Горик}

У статті розглядаються питання підвищення довговічності $і$ надійності робочих органів грунтообробних машин у процесі їх відновлення (виготовлення) з використанням вібраційних коливань, щзо сприяють інтенсифікації методів обробки, підвищенню рівня механізації та автоматизації багатьох трудомістких технологій. Показано залежність інтенсивності вібраційного зміцннення від наступних факторів: режиму обробки та фізико-механічних властивостей матеріалу оброблюваних деталей. Встановлено, щэо основними параметрами технологічного процесу вібраційного зміинення є збурювальна сила віброзбуджувача, амплітуда $i$ частота коливань обробного інструменту, ивидкість і час обробки.

Ключові слова: надійність, інтенсивність зношування, технологічний прочес, вібрачійне зміцнення, режими деформування.

Постановка проблеми. Скорочення державних закупівель призвело до різкого зниження придбання нової техніки. У цьому зв'язку машинно-тракторний парк скоротився, а навантаження на відповідну техніку зросло, що позначилося на зниженні іï довговічності за рахунок збільшення зносу деталей. Запасними частинами, що надходять у ремонтне виробництво, часто стають відбраковані у процесі складання нових машин деталі та складальні одиниці. Установка таких деталей на місце зношених не дає змоги досягти ресурсу нового з'єднання [3].

Відновлення деталей дає можливість підприємствам скорочувати час перебування машин у ремонті, підвищувати якість технічного обслуговування та ремонту, що позитивно впливає на поліпшення показників використання машин [5].

Економічна сторона доцільності проведення робіт із відновлення деталей полягає в зниженні собівартості ремонтних робіт за рахунок змен- шення витрат на нові запасні частини, а також у скороченні виробничих витрат у процесі експлуатації.

У підвищенні надійності й довговічності робочих органів грунтообробних машин значна роль, на думку героя України, академіка-агроеколога С. С. Антонця, належить їх конструктивним виконанням [8]. Суттєво підвищити ресурс сільськогосподарських машин можна за рахунок застосування зміцнюючих обробок робочих поверхонь деталей [4].

Актуальність досліджуваної теми обумовлена необхідністю вибору ефективного методу відновлення стрілчатих лап культиваторів методом вібраційного зміцнення, а також обгрунтування режимів. Відновлення роботоздатності деталей вібраційним деформуванням залишається актуальним, оскільки забезпечує високу якість і економічність технологічного процесу.

Аналіз останніх досліджень і публікацій, у яких започатковано розв'язання проблеми У процесі роботи культиваторів змінюються розміри і форма лап, що викликає зміну величини тягового опору, яка залежить також і від фізико-механічних властивостей грунту, глибини обробки та швидкості руху агрегату [2].

Характер зношування лап передусім залежить від вологості грунту, яка на глибині культивації протягом сезону змінюється значно більше, ніж на глибині оранки, і зі зменшенням якої верхня грань ріжучої кромки зношується активніше [7].

Характер і величина зносу лап впливає на стійкість культиватора по глибині обробки. Від утворення в процесі роботи потиличної фаски відбувається виглиблення лапи культиватора.

Граничний знос лап по ширині захоплення настає після того, як перекриття сліду лапи першо- 


\section{ТЕХНІЧНІ НАУКИ}

го ряду лапою другого ряду знизиться до 1015 мм, а зрізання бур'янів погіршується через порівняно незначний шлях ковзання їх коренів по лезу. Інтенсивність зносу культиваторних лап настільки велика, що в окремих випадках потреба у ремонті виникає через 2-3 години його роботи.

На якість обробки грунту значний вплив робить стан носка і леза лап культиватора, працездатність якого визначається гостротою і величиною їх зносу. Отже, у ході відновлення культиваторних лап необхідно досягти підвищення твердості і зносостійкості носка і леза лап, що дасть змогу підвищити їх довговічність.

Дослідження взаємодії абразиву з поверхнею робочого органу показали, що для збільшення довговічності необхідно підвищити абразивну зносостійкість.

Певної ефективності в підвищенні довговічності нових і відновлених деталей досягли за кордоном. Так, у Німеччині Науково-дослідний центр (м. Шарлоттенталь) розробляє нові технології відновлення зношених деталей зварюванням, наплавленням, металізацією, пластичною деформацією, полімерними матеріалами.

У Польщі технологічні процеси відновлення деталей розробляються Науково-технічним центром обслуговування сільського господарства (м. Лодзь).

На одному 3 великих підприємств компанії «Катерпіллер» (США) створено спеціалізовану ділянку для відновлення наплавленням ходової частини гусеничних тракторів.

У разі відновлення лап культиваторів зазвичай застосовують такі методи: відтяжка, вирізання зношеної частини леза лапи газоплазмовим різаком із наступним приварюванням профільної пластини зі сталі 65Г. Однак ці методи мають велику трудомісткість і не дають можливості отримати високу зносостійкість.

Існують дослідження 3 відновлення робочих органів грунтообробних машин наплавочним порошковим дротом і наплавленням наморожуванням на заготовку [1].

Для підвищення довговічності робочих органів іноді застосовують магнітоелектричний спосіб зміцнення.

Слід зазначити, що, незважаючи на важливість питання відновлення і зміцнення робочих органів культиваторів, ефективні засоби підвищення їх зносостійкості остаточно не обгрунтовані і в ремонтному виробництві недостатньо або й зовсім не використовуються.
Мета і задачі досліджень. Мета роботи підвищення довговічності стрілчатих лап культиваторів шляхом вібраційного зміцнення під час їх відновлення.

Задачами досліджень є:

- дослідити вплив вібраційної обробки на характер зміцнення;

- визначити оптимальні параметри вібраційного деформування;

- провести оцінку зносостійкості відновлених культиваторних лап i технологічного процесу вібраційного зміцнення.

Методи та методика досліджень. Методика досліджень полягала в теоретичному та експериментальному обгрунтуванні методу відновлення культиваторних лап, його основних технологічних параметрів. Теоретичні дослідження грунтувалися на використанні математичного аналізу. Експериментальні дослідження виконувалися 3 використанням методів математичної статистики і методів багатофакторного експерименту.

Результати досліджень. На підставі аналізу публікацій щодо підвищення довговічності лап культиваторів були виявлені наступні напрями досліджень:

- розробка високоефективного технологічного процесу відновлення зношених поверхонь ріжучих елементів культиваторних лап;

- підвищення довговічності стрілчастих лап культиваторів шляхом застосування методу вібраційного зміцнення.

Одним із важливих чинників у застосуванні технологічного процесу відновлення зазначених деталей $\epsilon$ вибір параметрів їх обробки, що визначають величину зносу ріжучих елементів.

Мікрометраж товщини ріжучої кромки культиваторних лап здійснювали мікрометром МКЦ25 із цифровим відліковим пристроєм із точністю відліку 0,001 мм (ГОСТ 6507-90), а вимірювання основних кутів лапи виробляли цифровим кутоміром із точністю відліку 5'. Геометричні параметри лап заміряли штангенциркулем ШЦЦ-500 із точністю відліку 0,01 мм.

Статистичну обробку отриманих даних здійснювали за допомогою програми Microsoft Excel.

Дослідження зі зміцнення лап методом вібраційного деформування проводили на виготовленій нами установці (рис. 1), що сприяє зміцненню поверхонь різних деталей із необхідними параметрами обробки: збурювальна сила, амплітуда і частота коливань обробного інструменту, швидкість його руху. 


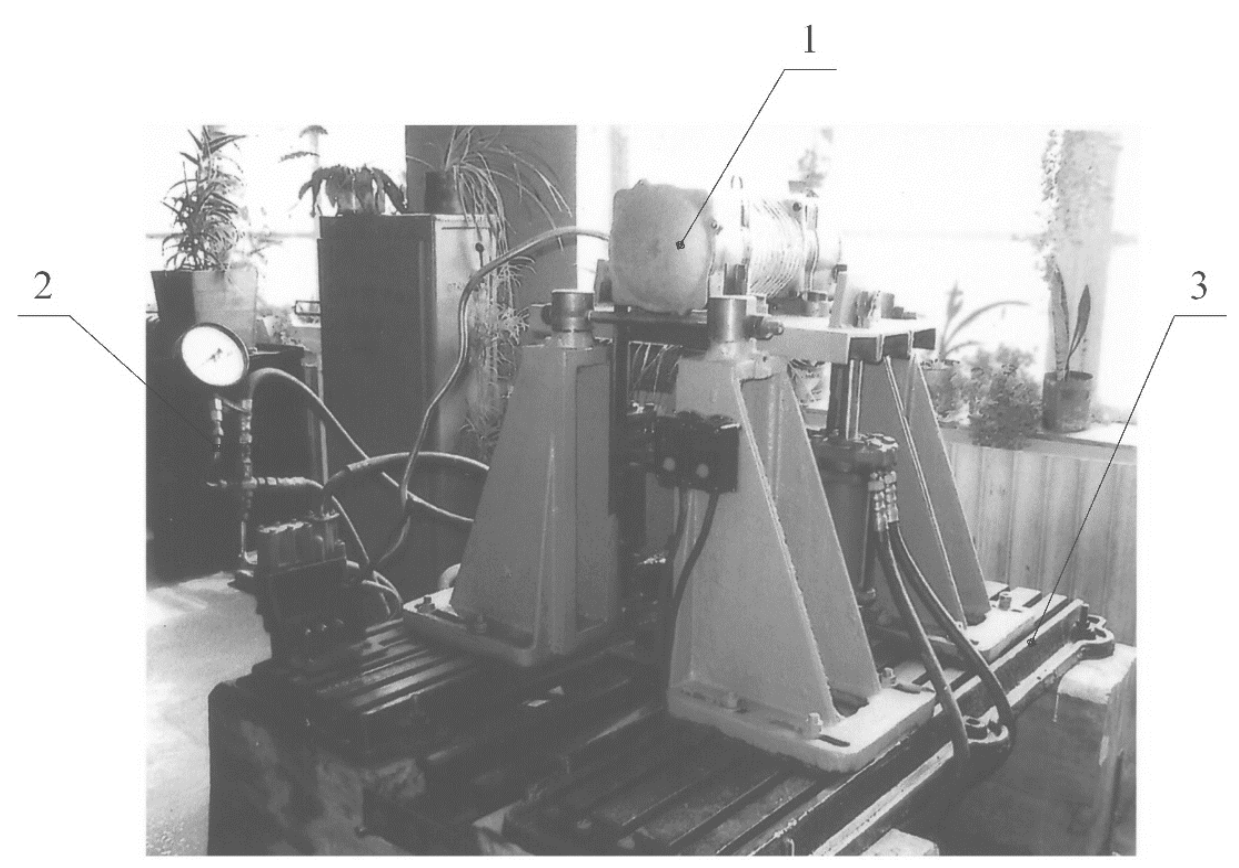

Рис. 1. Загальний вигляд вібраційної установки: 1 - віброзбудник; 2 - гідравлічна система; 3 - основи з допоміжним обладнанням

Схема вібраційної установки показана на рисунку 2.

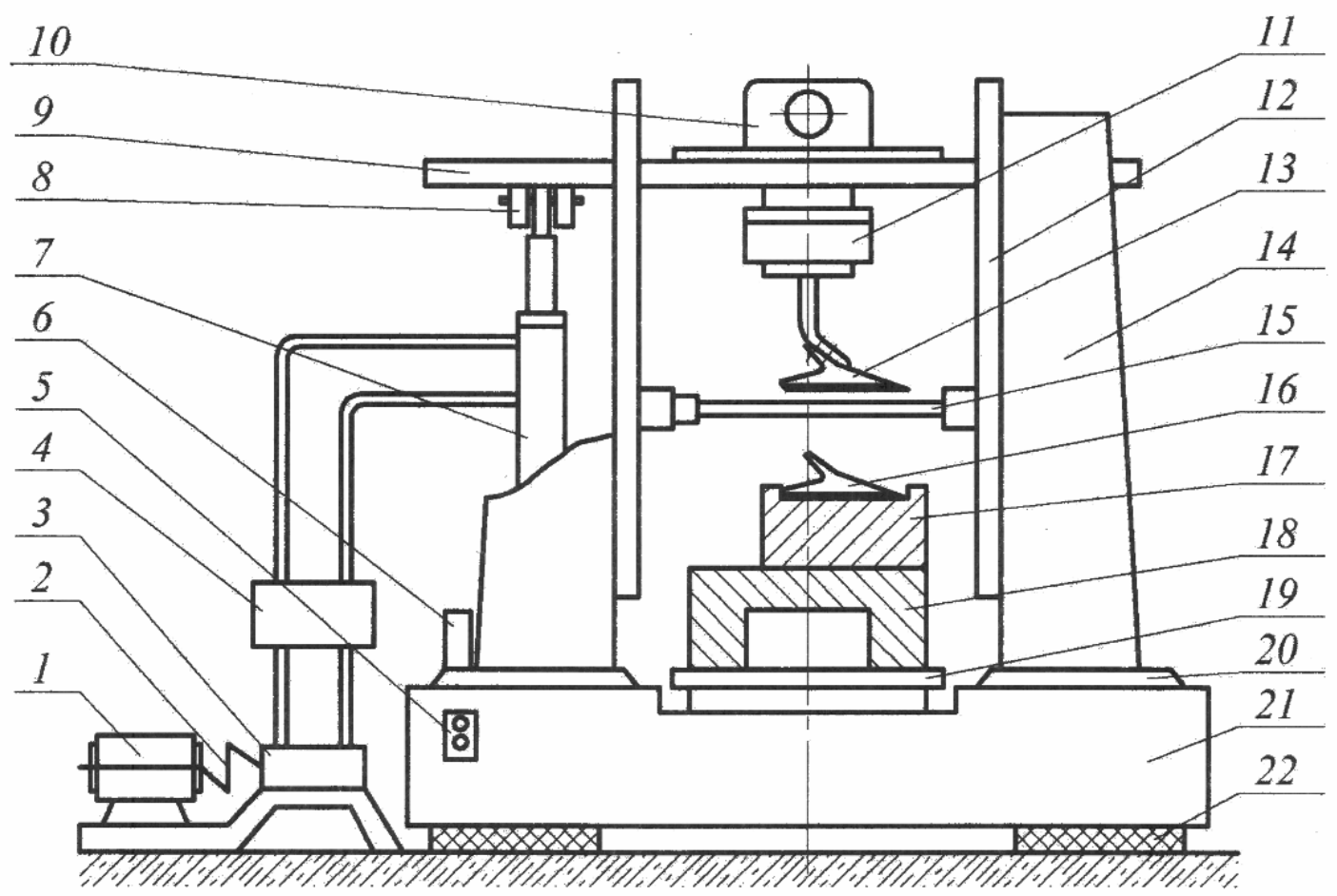

Рис. 2. Схема вібраційної установки: 1 -електродвигун: 2 -муфта; 3 - гідронасос; 4 -розподільник; 5 - пускач; 6 -бачок; 7 - гідрочиліндр; 8-гумові амортизатори; 9 - плита вібратора; 10 - вібратор; 11 - затискний пристрій; 12 - напрямна; 13 - робочий інструмент; 14 -стійка; 15 - стяжка; 16 -матриия; 17 - деталь; 18 -підстава; 19 -плита; 20 -опорна плита; $21-$ брус; 22 - амортизатор 
Стрілчасті культиваторні лапи в процесі роботи піддаються абразивному зношуванню, яке призводить до зменшення розмірів і затуплення їх леза, що викликає зниження ефективності роботи робочих органів.

У процесі зміцнення деталей вібраційним деформуванням пластична деформація поверхневого шару матеріалу змінює його фізико-механічні властивості, що значною мірою пояснюється зростаючим у міру деформування опором зсуву дислокацій [6].

За вібраційного навантаження кут перетину ліній ковзання 3 оброблюваною поверхнею змінюється від $45^{\circ}$ до $90^{\circ}$. Таким чином, у момент відриву обробного інструменту зусилля обробки буде направлено під більшим кутом до напрямку його руху, тобто зусилля, ступінь ущільнення і величина деформації в радіальному напрямку матиме більше значення, ніж за звичайного деформування.

Ступінь зміцнення оброблюваного матеріалу може бути визначена:

$$
\eta=\frac{F_{0}}{F_{1}}
$$

після деформування.

Розрахункові значення ступеня зміцнення матеріалу поверхні наведені у таблиці. Дослідженнями встановлено, що ступінь зміцнення зразків зі сталі $65 \Gamma$ із наступним наплавленням сормайтом і вібраційним зміцненням у 1,38 разу більше, ніж за звичайної обробки.

Для експериментального підтвердження розглянутих теоретичних передумов щодо доцільності використання технології вібраційного зміцнення лап нами були визначені такі їх параметри (рис. 3): ширина захвату (b); відстань від першого отвору до носка - довжина носка (a); ширина крила на кінці лез (c); товщина ріжучої кромки на відстані 2 мм (h).

Стендові випробування проводилися на восьми лапах наступних варіантів: нові зі сталі $65 \Gamma$; відновлені відтягненням нагрітих лап; відновлені дуговим наплавленням під шаром флюсу; відновлені дуговим наплавленням під шаром флюсу і вібраційним зміцненням.

Дослідженнями встановлено, що величина зносу носка нових лап у 1,54-1,67 рази більше, ніж ширини захвату крила.

де: $\mathrm{F}_{0}$ i $\mathrm{F}_{1}$ - площі оброблюваної поверхні до $\mathrm{i}$

\section{Значення ступеня зміцнення}

\begin{tabular}{|c|c|c|}
\hline \multirow{2}{*}{ Оброблюваний матеріал } & \multicolumn{2}{|c|}{ Значення $\eta$} \\
\cline { 2 - 3 } & $\begin{array}{c}\text { звичайне } \\
\text { деформування }\end{array}$ & $\begin{array}{c}\text { вібраційне } \\
\text { деформування }\end{array}$ \\
\hline 1. Сталь 65Г & 0,037 & $0,0,54$ \\
\hline 2. Сталь Л-53 & 0,040 & 0,059 \\
\hline 3. Сталь 65Г, сормайт & 0,032 & 0,044 \\
\hline 4. Сталь Л-53, сормайт & 0,035 & 0,058 \\
\hline
\end{tabular}
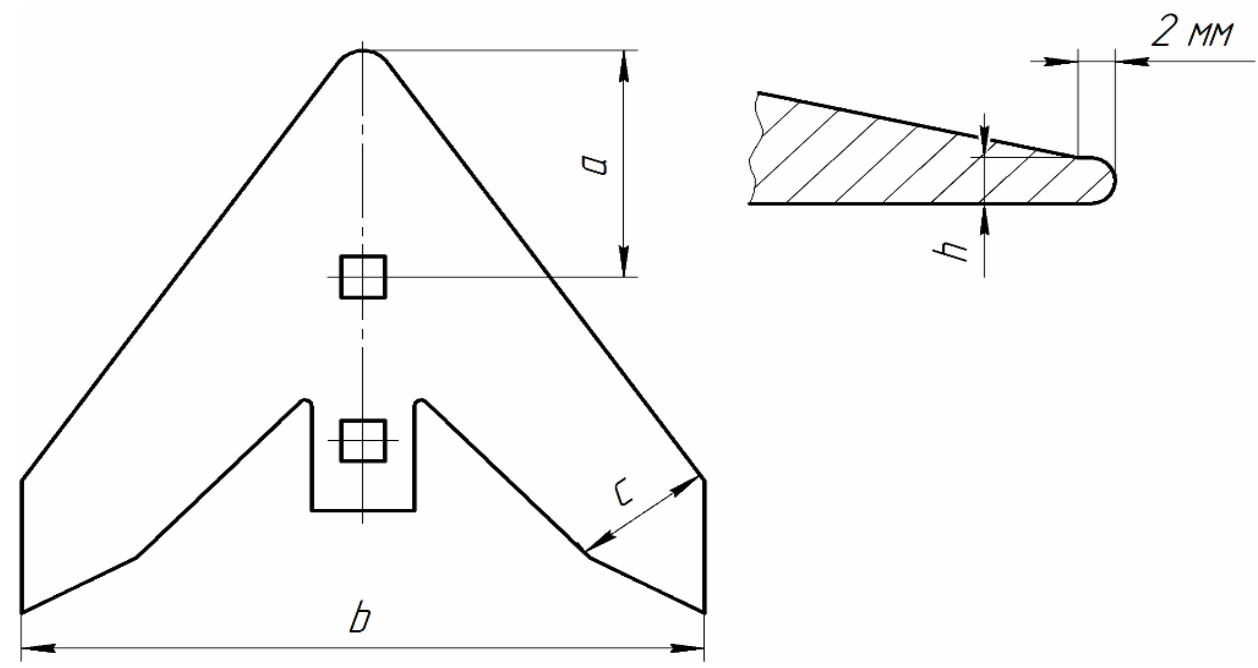

Рис. 3. Контрольовані розміри лапи 


\section{ТЕХНІЧНІ НАУКИ}

Дані вимірювання параметра (a) склали: для нових лап - 42-47 мм; відновлених відтягненням нагрітих лап - 50-57 мм; відновлених наплавленням сормайтом - 39-41 мм; відновлених наплавленням сормайтом і вібраційним зміцненням - 34-36 мм. Таким чином величина зносу носка четвертого варіанта лапи в 2,14-2,24 рази менше в порівнянні зі зносом нових культиваторних лап.

Одним 3 основних параметрів відновлення робочих поверхонь культиваторних лап $\epsilon$ величина деформації, що служить для компенсації їх зносу. Дослідженню піддавали зразки - лапи товщиною леза 0,5 мм, із кутом розхилу $2 \gamma=65^{\circ}$ i твердості ріжучої кромки лапи 48-54 HRC.

Дослідження показали, що характер зміни ширини леза і зменшення його товщини для даного значення амплітуди обробного інструменту ідентичний. Найбільше значення зазначених величин мало місце за амплітуди коливання $\mathrm{A}=$ 0,5 мм, а найменше - за $\mathrm{A}=0,75$ мм.

Такий характер зміни зазначених параметрів можна пояснити тим, що за амплітуди $\mathrm{A}=$ 0,25 мм недостатньо проявляються якості вібраційних коливань обробного інструменту. За амплітуди $\mathrm{A}=0,75$ мм відбувається менший контакт інструменту 3 оброблюваною поверхнею в результаті більшого його відриву. В цьому разі навантаження на оброблюваний матеріал носить ударний характер, що призводить до зниження його пластичності. Так, за амплітуди $\mathrm{A}=0,5$ мм величини приросту ширини леза лапи в 1,12 рази більше, ніж за $\mathrm{A}=0,25$ мм і в 1,37 - за $\mathrm{A}=$ 0,75 мм. Зменшення товщини леза лапи, відповідно, склало 1,21 і 1,42 разу.

Результати зносних досліджень (рис. 4) показали, що на кривих зносу виділяється два характерних періоди.

Перший тривалістю випробувань до 30 хв характеризується підвищеним ваговим зносом, а другий - стабільним зношуванням випробовуваних зразків. Динаміка зношування в цей період має характер, близький до лінійного.

Найбільш інтенсивно зношуються зразки, відновлені відтягненням нагрітих лап 2,8 г, а найвища зносостійкість $(1,4$ г) у лап, відновлених дуговим наплавленням під шаром флюсу та зміцнених вібраційним деформуванням, тобто вдвічі менше.

На випробування були поставлені лапи чотирьох варіантів:

- нові зі сталі 65Г;

- відновлені відтягненням нагрітих лап;

- відновлені дугового наплавленням під шаром флюсу;

- відновлені дугового наплавленням під шаром флюсу та зміцнених вібраційним деформуванням.

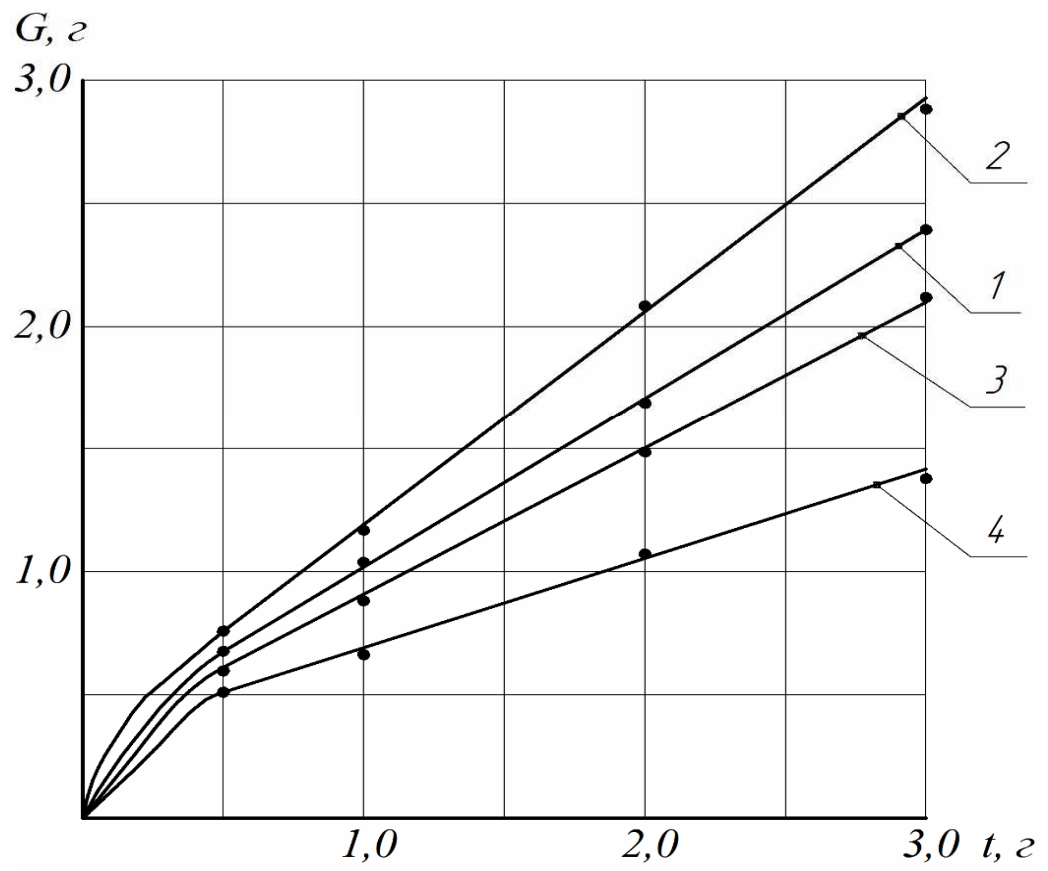

Рис. 4. Залежність вагового зносу зразків від варіанта і часу випробування: 1 - нові зі сталі 65Г; 2 - відновлені відтягненням нагрітих лап; 3 - відновлені дуговим наплавленням під шаром флюсу; 4 - відновлені дуговим наплавленням під шаром флюсу і вібраційним деформуванням 
Експлуатаційні випробування проводяться в державному підприємстві дослідного господарства «9 січня» Хорольського району Полтавської області на культиваторі КПС-4.

\section{БІБЛІОГРАФІЯ}

1. Бетеня Г. Ф. Нанесение износостойких покрытий при упрочнении и восстановлении почворежущих элементов наплавкой намораживанием / Г. Ф. Бетеня, Н.В.Кардаш, Н.А.Зайко [и др.] // Защитные покрытия на металлы. - 1990. - Вып. 24. - С. 94-97.

2. Войтюк Д. Г. Сільськогосподарські машини / Д. Г. Войтюк, Г. Р. Гаврилюк. - К. : Каравелла, 2004. - $552 \mathrm{c}$.

3. Дудніков А. А. Проектування технологічних процесів сервісних підприємств / А. А. Дудніков, П. В. Писаренко, О. І. Біловод [та ін.] - Вінниця : Наукова думка, 2011. - 400 с.

4. Проблема реалізації технічної політики в агропромисловому комплексі / За ред. Я. К. Білоуська. - К. : ННЦ «IAE», 2007. - 215 с.
Висновок. Отримані дані в процесі експлуатаційних випробувань дадуть змогу використовувати їх для розробки технологічних операцій як у процесі відновлення культиваторних лап, так і в їх виготовленні.

5. Рибак T. I. Пошукове конструювання на базі оптимізації ресурсу мобільних сільськогосподарських машин / Т. І. Рибак. - Т. : ВАТ «ВПК», 2003. - $332 \mathrm{c}$.

6. Сторожев М. В. Теория обработки металлов давлением / М. В. Сторожев, Е. А. Попов. - М. : Машиностроение, 1997. $-423 \mathrm{c.}$

7. Ткачев В. Н. Износ и повышение долговечности деталей сельскохозяйственных машин / В. Н. Ткачев. - М. : Машиностроение, 1971. $264 \mathrm{c}$.

8. Черкас В. М. Автограф на землі. Фоторозповідь про життя і творчість Семена Свиридоновича Антонця / В. Черкас. - Полтава : ТОВ «Симон», 2013. -288 c. 